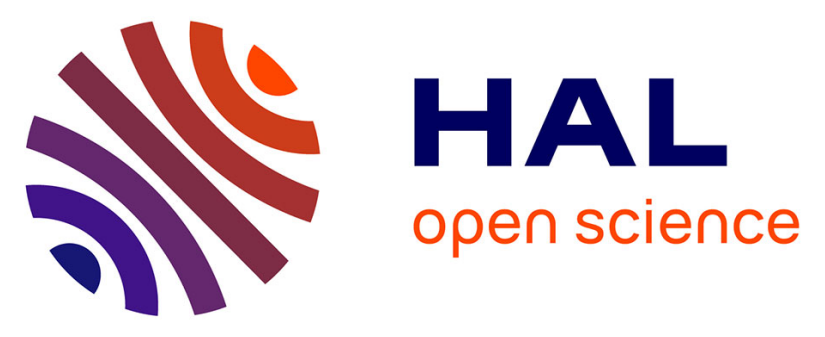

\title{
Information science in France. Emergence, Evolution and Perspectives
}

Fidelia Ibekwe-Sanjuan

\section{To cite this version:}

Fidelia Ibekwe-Sanjuan. Information science in France. Emergence, Evolution and Perspectives: In LIBRARY AND INFORMATION SCIENCE TRENDS AND RESEARCH: EUROPE, Amanda Spink \& Jannica Heinstrom (eds.). Amanda Spink and Jannica Heinström. In, LIBRARY AND INFORMATION SCIENCE TRENDS AND RESEARCH: EUROPE, Emerald Insight, pp.273-295, 2012, Emerald Library and Information science book series, 978-1-78052-714-7. 10.1108/S18760562(2012)0000006015 . hal-00681931

\section{HAL Id: hal-00681931 https://hal.science/hal-00681931}

Submitted on 29 Mar 2012

HAL is a multi-disciplinary open access archive for the deposit and dissemination of scientific research documents, whether they are published or not. The documents may come from teaching and research institutions in France or abroad, or from public or private research centers.
L'archive ouverte pluridisciplinaire HAL, est destinée au dépôt et à la diffusion de documents scientifiques de niveau recherche, publiés ou non, émanant des établissements d'enseignement et de recherche français ou étrangers, des laboratoires publics ou privés. 
Ibekwe-SanJuan F., Information science in France. Emergence, Evolution and Perspectives. In. Library and Information Science Trends in Europe, Amanda Spink and Jannica Heinstrom (eds.), Emerald Library and Information science book series $1 / 17$

\title{
Information science in France. Emergence, Evolution and Perspectives
}

\author{
Fidelia Ibekwe-SanJuan \\ Associate Professor \\ Department of Information \& Communication Studies \\ University of Lyon 3 \\ 6, cours Albert Thomas \\ 69008 Lyon - France \\ fidelia.ibekwe-sanjuan@univ-lyon3.fr
}

\begin{abstract}
As an academic specialty in the French higher education, Information Science was shaped by short-term government policies implemented after world war II until the late nineties. The field was officially recognised in 1974 as part of when an interdisciplinary field named "Information and Communication Science". Information Science was seen by the successive French governments as an instrument with which to gain information independence from the United States. The aim of was to develop information infrastructures (telecommunications, databases, servers), hence to develop an industry rather than a science. This led to narrowing the focus of the field to only one type of information - scientific and technical information. The first higher education curricula and doctoral programs were technologically-oriented, driven by the need to train information professionals rather than scientists. Little attention was paid to research on conceptual models, on theories and on knowledge organisation which used to be the stronghold of European and French pioneers in bibliography and in documentation (Paul Otlet, Suzanne Briet, Georgette and Eric de Grolier among others). Currently, the trend is to bring information science back to its humanistic origins and to engage in a more theoretical and people-oriented research. However, there is yet no coherent agenda that clearly defines what information science research should be about. There is also little visibility of French information science both at the national and international arena.
\end{abstract}

\section{Introduction}

The foundations of Library and Information Science (LIS) were laid by Paul Otlet and Henri Lafontaine in the late $19^{\text {th }}$ century and later by Suzanne Briet, a French librarian and pioneer in information science in the mid $20^{\text {th }}$ century. Paul Otlet had coined the term Documentation as early as 1903 to describe a new field of study. As Williams (1997: 776) recalled, "Otlet believed that documentation should be concerned with any records and objects that had the potential of providing useful information, and that offices of documentation should be created to carry out this work". However, the emergence of information science (IS henceforth) as a scientific field in the French higher education system only came about in the mid-seventies. It was precisely in 1974 that a composite field named "Information \& Communication Sciences" (ICS) was carved out of existing university disciplines in France. Hence, the "information science" branch (IS) is embedded within the composite field of ICS. Library science or what stands for it in France (bibliothéconomie $^{l}$ ) is managed by librarians.

To better understand the current state of IS and why it occupies so little a place within the French higher education system and the academic community, it is necessary to go back to the political and institutional contexts in which the ICS field emerged. For this, we relied on earlier accounts given by several authors and in particular by (Salaün 1991 \& 1993), by Palermiti \& Polity (2002)

\footnotetext{
${ }^{1}$ Literally "the economy of libraries".
} 
Ibekwe-SanJuan F., Information science in France. Emergence, Evolution and Perspectives. In. Library and Information Science Trends in Europe, Amanda Spink and Jannica Heinstrom (eds.), Emerald Library and Information science book series $2 / 17$

and by Tétu (2002).

In their study, Palermiti \& Polity (2002) looked at some tangible things by which the evolution of a field may be measured, namely the state of its higher education training (departments, students, curricula), avenues for scholarly publications, the number of doctoral thesis defended in the field, the presence and number of dedicated conferences, the existence of manuals which help in disseminating fundamental knowledge in the field. Their study covered the first two decades of existence of IS (1974-1994). Building on results of this earlier study, we will update it to the current period (2012) and look at other criteria such as governance and research assessment which have become significant factors in shaping the current landscape and also the future of information science in France. This chapter is the first part in a series of analysis of the landscape of Information science in France. A more conceptual piece, comparing the french conception to the Anglophone conception of information science is offered in Ibekwe-SanJuan (2012).

\section{The political context of emergence of Information Science}

Jean-Michel Salaün (1991, 1993), then Cacaly and Le Coadic (2007) have written detailed accounts of the French public policy on scientific and technical information (STI) in the postWWII period (1955 - 2005). We will recall only the salient points here. Basically, the different governments relied on a couple of bodies, in particular, the French national research agency $\left(\mathrm{CNRS}^{2}\right)$ and experts coming from nuclear energy industry $\left(\mathrm{CEA}^{3}\right)$ or from the Defense ministry. Public policy on information did not seek the opinion of scholars from the humanities because IS was first and foremost seen as a tool to advance a strategic political agenda - that of building information highways (telecommunication networks, servers).

Competing conceptions of what the nation required in terms of information infrastructure were tendered by these experts: the CNRS advocated a centralised structure which of course will be managed by them, while several groups of experts pleaded for a decentralised one. The competition between government agencies and expert groups was not helped by another political factor: change of power at the very top of the state owing to elections. Three political parties shared power in the decades after WWII: first the Gaullist party, the centrist party and then the socialist party. The consequence for IS was a discontinuity in government policy on information according to changes in political party.

\section{Impact of successive political parties on information science}

The Gaullist party that ruled France for fifteen years after WWII laid the emphasis on a "plan calcul" (a grand plan for computation). The "Rapport Boutry » of 1964, commandeered for the government and named after its author, proposed a policy for the dissemination of STI and laid the foundations of a national policy. This was at a time when the world was witnessing an exponential growth in document production but without the adequate storage and retrieval facilities. The Boutry report advocated a national coordinated effort to manage this document explosion, led by the documentation center of the CNRS, in association with other scientific documentation centers. Not unlike the reaction of the American central government following the

\footnotetext{
${ }_{3}^{2}$ Centre National de Recherche Scientifique (The French national institute for scientific research.)

${ }^{3}$ Commissariat à l'Energie Atomique. (The Commissary for Atomic Energy).
} 
Ibekwe-SanJuan F., Information science in France. Emergence, Evolution and Perspectives. In. Library and Information Science Trends in Europe, Amanda Spink and Jannica Heinstrom (eds.), Emerald Library and Information science book series 3/ 17

launching of the Sputnik satellite by the ex-USSR in 1957, the Gaullist ${ }^{4}$ policy in France saw scientific information as a tool with which to advance its political agenda and gain its independence from the two blocks - the ex-USSR and the USA. In the post-WWII context of star wars, where countries were focused on arms building and nuclear power, STI became an issue of national priority and the government set out to encourage the technical development of the sector. As Salaün (1991) noted, this had the unhappy consequence of preventing any real debate on the issue since STI was presented as a matter of national sovereignty. Some of the earliest and most effective documentation centers were housed within the ministry of defense $\left(\mathrm{CEDOCAR}^{5}\right)$ and the center for atomic energy (CEA). This signaled a symbolic shift of focus from "documentation" to STI and from humanities (Paul Otlet and Briet's vision) to technology and to industry.

The fact that governmental policy on information was reduced to an instrumental and technical approach was also due to the small group of influential men from the sciences who were the thinkers and implementers of such policies - Pierre Aigrain (nuclear physics), Jacques-Emile Dubois (chemistry), Jacques Michel (chemistry). A huge effort was deployed in creating bibliographic databases in physics and chemistry in order to gain independence from the american monopoly in these areas (Chemical abstracts). This situation, as Salaün (1991) recalled, is not peculiar to France nor is it specific to the post-WWII era. Indeed scientists and especially chemists enjoyed privileges in the period preceding the Nazi regime in Germany and some were closely associated with the Nazi's rise to military supremacy. As Fayet-Scribe (1997) recalls, "After the end of World War I, in fact, there was an awareness in France of the necessity for a national effort in the realm of what we now call technical and scientific information. Thanks to its wealth of bibliographies, German science had created a monopoly situation, and closure of the borders had halted the flow of publications, a penury that brought home the importance of access to information (Gablot, 1991). »

The election of Valéry Giscard D'Estaing in 1974 from the centrist party as president of France signaled a swing in the government's policy on STI. The "plan calcul" promoted by the former Gaullist government was abandoned in favour of a "plan telephone" (a grand plan for telecommunication infrastructures). This change was made popular by the landmark "Nora-Minc" report of 1978, also named after its authors, entitled "L'informatisation de la sociétét". In this report, information was compared to energy, a resource of which the society was in dire need. This vision of information was heavily influenced by the Shannon-Weaver theory of mathematical communication which then became the basic theory of information and of IS, thus severing the links with library and documentation which until then had been the historical roots of the discipline. The apparent progress encountered in computer science at that time made information processing more accessible. It was also in this report that the neologism "télématique", a contraction of "informatique" (informatics) and "télécommunications", was introduced. As Salaün (1991:15) observed : "With this report, information gained a higher status and acquired its "lettres de noblesse". However its role was never clearly defined and there was a confusion between

\footnotetext{
${ }^{4}$ Political ideas assimilated with Charles de Gaulle's republican party.

${ }_{6}^{5}$ Centre de documentation des Armées (The documentation Center of the Army)

${ }^{6}$ The computerisation of society.
} 
Ibekwe-SanJuan F., Information science in France. Emergence, Evolution and Perspectives. In. Library and Information Science Trends in Europe, Amanda Spink and Jannica Heinstrom (eds.), Emerald Library and Information science book series $4 / 17$

informatics and information. This confusion was maintained by the telecommunication industry which owing to its development of telephone lines in rural France suddenly became a prominent actor in the information sector in the late seventies. Not surprisingly, the conception that the telecommunication industry had of information was different from that of LIS scholars. Information for the telecommunications industry was not something which had content, meaning and could be analysed but rather something which can be transported, whose volume can be measured, and whose influx can be observed. Databases, servers and big documentation centers were being compared to grey petrol (pétrole gris). Information, assimilated with informatics and «telematics », was being presented as a means to get out of the economic depression of the midseventies. Hence, information became an industry and the term 'Information Society' (société de l'information) became popular and «passe partout» from the 1980s.

The arrival of François Mitterand and the socialist government to power in 1981 signaled yet another change in focus. Efforts were then deployed towards the democratisation of informatics and towards scientific communication. At a national conference convened by Jean-Pierre Chevènement, the then socialist minister of research and industry, it was brought home for the first time to the scientific community that publication of results of its research was obligatory. This was actually translated as a law, voted by the Parliament in in 1982 (Cacaly \& Le Coadic, 2007).

\section{Ministerial bodies in charge of implementing information-oriented policies}

The ministerial bodies created from the early seventies to advise the successive governments and implement information-related policies had an ephemeral existence before being dissolved and replaced by others. The development of STI infrastructures was led by the "Commisariat general au plan" who created the office of STI (BNIST ${ }^{7}$ ) in 1973 - "the first in a long series of ministerial agencies whose abbreviations ended with IST" (Salaün 1993). The BNIST is the " counterpart of the Committee on Scientific and Technical Information (COSATI) in the U.S. » (Fayet-Scrbe 1997). An attempt to group the different ministerial bodies in charge of STI resulted in the creation of the DBMIST $^{9}$ in 1982. After some positive results (creation of centers for acquisition and dissemination of STI - the CADIST ${ }^{10}$, creation of several training centers for STI - the URFIST ${ }^{11}$, of the national university server system the SUNIST ${ }^{12}$ in 1984, the creation of INIST ${ }^{13}$ by the CNRS, in 1988 which hosts the two bibliographic databases PASCAL and FRANCIS), the DBMIST was dissolved in 1990. The PARUSI ${ }^{14}$ plan was then devised by the government to try and balance the power tussle within the discipline between information science and communication science. Unfortunately, this failed as later events will show.

As Salaün (1993) observed, "[...] this inflation of governmental agencies on STI signaled the shifting of focus from "biblio- "(as in bibliothéconomie") - thus from books and documents to "STI" signaling a change of object and the fact that the focus of analysis is henceforth on

\footnotetext{
${ }^{7}$ Bureau National d'Information Scientifique et Technique. (National Bureau for Scientific and Technical Information)

${ }^{8}$ Information Scientifique et Technique. (Scientific and Technical Information).

${ }^{9}$ Direction des Bibliothèques, des Musées et de l'Information Scientifique et Technique. (Direction for Libraries, Museums \& Scientific and Technical Information)

${ }^{10}$ Centres d'Acquisition et de Diffusion de l'l'Information Scientifique et Technique. (Center for Acquisition \& Dissemination of Scientific and Technical Information).

${ }^{11}$ Unité Régionale de Formation à l’Information Scientifique et Technique. (Regional training center for Scientific and Technical Information)

${ }^{12}$ Serveur Universitaire National pour l'Information Scientifique et Technique. (National University Server for Scientific and Technical Information)

${ }^{13}$ Institut national de l'information scientifique et technique. (National Institute for Scientific and Technical Information).

14 "Plan d'aide à la recherche universitaire en science de l'information. » (Programme of aid towards scientific research in information science)
} 
Ibekwe-SanJuan F., Information science in France. Emergence, Evolution and Perspectives. In. Library and Information Science Trends in Europe, Amanda Spink and Jannica Heinstrom (eds.), Emerald Library and Information science book series $5 / 17$

technocratic issues. The result was not the building of a science but of structures concerned not with documents but with information ${ }^{15}$."

Inconsistency in government policies owing mainly to power swings between left and right wing parties resulted in an incoherence which negatively affected the epistemological and conceptual emancipation of the field. The global result was that management of the IS sectors by the different French government displayed an unfortunate characteristic trait of the french administration "a jacobine ${ }^{16}$ centralization, a policy of "pré-carré" undertaken by the different government agencies and a general absence of coordination between the different government bodies" (Palermiti \& Polity 2002). Information science was delivered to different interest groups who influenced government policies for about forty years.

More fundamentally, the narrowing of focus on only scientific and technical information (STI) was at odds with the view that the founding figures of european documentation (Paul Otlet, Henri Lafontaine and Suzanne Briet) had of documents and of information which was a very open one, encompassing all types of documents not just scholarly documents, and under all their forms, not just written, and destined to all types of public. The consequence of the instrumental approach to IS in France in the decades following WWII was that the wider conceptual approach to documents advocated by Briet and Otlet in the early $20^{\text {th }}$ century was forsaken. The narrow and technical conception of information implemented by ministerial agencies has had lasting repercussions on higher education curricula and on the orientation of research in IS.

Moreover, the precise nature of the STI was not clearly defined although it seemed to be mostly limited to "documentary information", i.e, units already extracted and entered into databases that have acquired a certain degree of autonomy from their source (context of creation). Organising documentary information became a service delivered to other disciplines. Hence STI infrastructures (documentation centers, databases) were perceived first and foremost as serving the scientific community.

\section{Professional training in Library and Information Science}

Not surprisingly, the incoherent government policies trickled down into the higher education system for IS. Training programs for librarians, archivists and documentalists which existed prior to the emergence of the ICS field were not associated with nor integrated into the nascent field. Furthermore, librarians and documentalists were divided, had competing bodies and different training curricula despite the fact that they shared a common history and relied on the same fundamental concepts for designing and maintaining knowledge organisation systems. This rivalry did not exist before WWII. Indeed the two bodes enjoyed a nice cooperation:

"The most significant contacts between documentalists and librarians in France took place during

\footnotetext{
${ }^{15}$ In the original text: "Alors qu'au début du siècle nos acteurs s'accrochaient au préfixe biblio- pour marquer que l'on appliquait une réflexion pluridisciplinaire au document, l'abus des "-ist" témoigne à la fois d'une démarche plus technocratique et d'un changement d'objet. On ne construit pas une science, mais des structures. Celles-ci ne traitent pas des documents, mais de l'information. » Salaün (1993).

16 This refers to the "concept of a centralized Republic, with power concentrated in the national government, at the expense of local or regional governments" - http://en.wikipedia.org/wiki/Jacobin_(politics)
} 
Ibekwe-SanJuan F., Information science in France. Emergence, Evolution and Perspectives. In. Library and Information Science Trends in Europe, Amanda Spink and Jannica Heinstrom (eds.), Emerald Library and Information science book series $6 / 17$

the 1895 - 1944 period. After World War II, however, there was a distinct breach between the two. " (Fayet-Scribe, 1997).

This breach between librarians on the one hand and documentalists (special librarians or information officers) is also referred to many times in Palermiti \& Polity (2002) : "Documentation centers and libraries co-existed, the latter sometimes being at the origin of the former and housing it within its walls. Pioneering figures such as Suzanne Briet, Louise-Noëlle Malclès, Yvonne Oddon, Myriem Foncin et Georgette De Grolier, were versatile, having worked in either structures, had a good knowledge of both. The two professions have the same history even if debates on documentation and libraries or precisely on the nature of documents arise now and then".

\section{Training schools for librarians}

Training courses for librarians and archivists have always been managed by special schools whose primary focus is on empirical studies. According to Fayet-Scribe (1997), until the creation of the Paris School of Library in 1923, "there was no French library school proper, apart from the Ecole des Chartres which was a school of archivists and guardian of the national heritage" although a Certificate of Aptitude to the function of librarian (Certificat d'Aptitude à la Fonction de Bibliothécaire) was created in 1879. The Paris Library School was supported by an American trust fund for devastated regions of which France was one after world war I (WWI). The school functioned from 1923 to 1929. Many of the first French librarians were trained by American librarians sent over to France to help set up public libraries. The all powerful American Library Association (ALA) funded the Paris Library School for many years before the French government was able to step in. This debt is acknowledged in Fayet-Scribe (1997) when she writes "Public librarianship [in France] owes much to the American model."

The first french run school of librarians, the ENSB ${ }^{17}$, was created in 1963. By a series of government reforms aimed at bringing such library schools closer to the university system, the ENSB became the ENSSIB $^{18}$ in 1992, in a move to move librarianship closer to information science and documentation. However, the overall orientation of the ENSSIB remains pragmatic and professional rather than conceptual and theoretical. Its main mission remains the training of librarians (les conservateurs). Students admitted into this school come predominantly from a history or literatures background. The training for librarians and museum curators has always been under the monopoly (mainmise) of historians and literatures, a situation decried by Eugene Morel, one of the first presidents of the "Bureau Bibliographique de France" as early as in 1910. The Bureau Bibliographique de France is the french counterpart to the Paul Otlet's Belgian International Institute for Bibliography (IIB). The consequence of this monopoly was that the policy pursued towards public libraries was influenced by the background of its administrators who did not have adequate training to deal with the technological challenges that libraries faced.

\section{Training schools for documentalists and information professionals}

The earliest training in documentation was created by a professional association of

\footnotetext{
${ }^{17}$ Ecole Nationale Supérieure des Bibliothèques.

${ }^{18}$ École Nationale Supérieure des Sciences de l'Information et des Bibliothèques.
} 
Ibekwe-SanJuan F., Information science in France. Emergence, Evolution and Perspectives. In. Library and Information Science Trends in Europe, Amanda Spink and Jannica Heinstrom (eds.), Emerald Library and Information science book series 7/ 17

documentation called the UFOD ${ }^{19}$ in 1945 , without much help from the ministry who was more focused in organizing the public library sector. Suzanne Briet was an influential member of the UFOD. The first institution of higher education for training "engineers in documentation" - the $\mathrm{INTD}^{20}$ was created in 1950. However, the same government agency (Direction des bibliothèques) that created the INTD, also created the rival institution of higher education for librarians - the ENSB at the same time, under pressure from the powerful lobby of librarians (conservateurs) (Palermiti \& Polity 2002).

Schools for librarians focused more on public literacy issues (lecture publique) while the INTD and universities had a more technologically-oriented curricula and produced technicians (documentalists) for the private sector.

Librarians have their own association, the $\mathrm{ABF}^{21}$, their journals and their institutions. Documentalists and information professionals congregate around another association - the $\mathrm{ADBS}^{22}$. The ADBS was formed in 1963 as a result of a split among the alumni students of the INTD. Its first initiative was the founding of a professional journal - Documentaliste, Sciences de l'information (Salaün, 1999).

Also, a difference in status opposes on the one hand state-trained librarians and archivists who work in the public sector (libraries, archives) and are civil servants, and documentalists and other information professionals on the other hand who work for the private sector.

The opposition between documentalists and librarians is not peculiar to France. Buckland (1996) gave an account of the influential role played by the Chicago School of Library in orienting the development of the field towards librarianship rather than to information science in the mid $20^{\text {th }}$ century. Williams (1997) also gave a detailed account of opposition, in the 1930s-1960s, between the American Library Association (ALA) and the Special Libraries Association (SLA) movement which is the american counterpart of documentation. SLA finally lost the battle to be recognized as a distinct profession with special needs in training, with special services to the public. The reason according to Williams was that they were not proactive enough in the face of technology and in subject indexing, despite the fact that a figure like Mortimer Taube, father of modern indexing techniques, was a prominent member of SLA. The so-called special librarians eventually became like general librarians. In fact, they received the same training since the ALA refused to implement specific teaching curricula in library schools for SLA (Williams, 1997).

\section{Higher education training in Information Science}

The higher education landscape in the first three decades (1975-2000) inherited the narrow political agenda for IS by the successive governments and ministerial bodies. The demarcations between training institutions and professional bodies for librarians and archivists on the one hand, and other information professionals (documentalists) on the other further institutionalised the divide and atomised the professional arm of the field.

\footnotetext{
${ }^{19}$ Union Françaises des Organismes Documentaires.

${ }^{20}$ Institut National des Techniques Documentaires.

${ }^{21}$ Association des Bibliothécaires de France. http://www.abf.asso.fr/

22 Association des Documentalistes et des Bibliothécaires Spécialisés, which has become "Association des professionnels de l'information et de la documentation". http://www.adbs.fr/
} 
Ibekwe-SanJuan F., Information science in France. Emergence, Evolution and Perspectives. In. Library and Information Science Trends in Europe, Amanda Spink and Jannica Heinstrom (eds.), Emerald Library and Information science book series $8 / 17$

IS curricula became a mosaic of which few had a full grasp and portrayed the lack of a coherent grand scheme. The academic community was disconnected from their professional institutions (archives, libraries, museums) in terms of research. Only the documentation sector was somewhat associated with the field's constitution. The consequence was that "the academic recognition of the discipline was done on the borderline of its already established cognitive institutionalization: only a little proportion of this heritage including professional, militants and scholars would join the academic constitution of IS, leaving by the roadside a part of the public institutions (libraries, museums, archives) and some researchers who had invested time on IS research." (Palermiti \& Polity, 2002).

As Palermiti \& Polity (2002) pointed out, the fundamental issue raised by this demarcation is the reluctance by the government to let the state funded universities handle the training of its elite. This is one of several "exceptions françaises": the distinction made between universities who are obliged to accept practically all freshmen candidates and the "Grandes Ecoles" who are very selective and function by entrance examination (concours ${ }^{23}$ ). Students who are lucky to be admitted into these special schools become "pupils of the State". Upon completion of their training, they are practically guaranteed a job placement in a public or private institution where they become top executives. However, the European Union, through the Bologna process may well signify the end of such "exceptions". There have been insistent noises from neighbouring European countries that such schools put some french pupils in a more privileged position than their european counterparts. It also runs counter to the european union's objective of "easily readable and comparable degrees organised in a three-cycle structure (e.g. bachelor-masterdoctorate) ${ }^{24 \text {, }}$ aimed at promoting students' mobility within Europe.

Before the official recognition of the field in 1974, a few training courses in information and communication were scattered in some university departments (mostly in literature departments). Higher education curricula in IS have been mostly focused on producing information professionals for the private sector. These professionals in return make up of half of the teaching staff as adjunct professors and bring 'on-the-field' experience for future professionals. Thus, IS as a university diploma, inherited the "instrumental" approach put in place by ministerial policies on STI. It is largely perceived by other disciplines as a specialty with a limited set of techniques that it can roll out when necessary to solve the practical problems, namely catalog, index, store and retrieve documentary information.

\section{The structure of graduate and post-graduate studies}

The earliest diploma in IS was a two-year technical undergraduate course $(\mathrm{Bac}+2)$ offered by Institutes of Technology ${ }^{25}$ affiliated with universities. The majority of the courses in IS typically begin either at graduate or post-graduate level and are often hosted in departments of Information

\footnotetext{
${ }^{23}$ A competition or contest which only a handful mange to pass, usually pupils who go through "les classes préparatoires" familiarly termed "prépa", an intensive two-year post-Bac preparation that prepares one to take this "concours" to enter into "les Grandes Ecoles" or "les Ecoles d'ingénieur" (Schools of Engineering).

${ }^{24} \mathrm{http}: / / \mathrm{www}$. ond.vlaanderen.be/hogeronderwijs/bologna/about/.

${ }^{25}$ Institut Universitaire de Technologie (IUT).
} 
Ibekwe-SanJuan F., Information science in France. Emergence, Evolution and Perspectives. In. Library and Information Science Trends in Europe, Amanda Spink and Jannica Heinstrom (eds.), Emerald Library and Information science book series $9 / 17$

and Communication Studies or in humanities departments (Literatures, History, Arts, Languages). IS rarely exists alone as a distinct specialty in a distinct department. With the notable exception of the ENSSIB in Lyon which is really a school for librarians, and the INTD in Paris, there are no such things as "Schools of Information Science" (iSchools) in France.

A few departments in universities offered a one-year accelerated course in the graduate year (third year) of university (Licence or Bac +3 ), a handful more offered a one-year masters' degree in documentation $(\mathrm{Bac}+4)$, enabling students from any other discipline to claim a "documentation" coating.

The earliest masters' degree programs were one-year courses created in Grenoble in 1970 (certificat de maîtrise d'informatique et documentation littéraire) and in Bordeaux in 1971. It was no coincidence that the first degrees (IUTs and masters) were set up in Bordeaux since this was where one of the founding father of the ICS discipline - Robert Escarpit did his career. Bordeaux was also the first and one of the rare universities to offer a complete university degree in ICS, going from undergraduate to post-graduate and to doctoral studies (Tétu, 2002).

Two types of post-masters' degrees led to obtaining an "engineer diploma" in information documentation, namely the $\operatorname{DESS}^{26}$ and the engineer diploma delivered by Institutes for professional studies $\left(\mathrm{IUP}^{27}\right.$ ), set up within universities.

The IUPs was a recognized diploma in information-documentation at a Bac +4 level, thus somewhere between a one-year masters' degree and a DESS. Students entering an IUP typically would have completed a one-year university course in another discipline.

Students who graduate from the two-year technical undergraduate course offered by IUTs did not always have a clear channel for pursuing an IS education at graduate and masters degrees. They would either have to get into university departments proper and possibly change cities in order to obtain a masters' degree in information-documentation. Hence, students applying to enter into a masters' degree would typically be from everywhere else. The consequence is a pluri-disciplinary population with very diverse academic backgrounds ranging from the sciences (chemistry, biology, physics) to mathematics, to economics, to arts, social sciences and humanities. Most students entering into an IS course would have had only one or two year's orientation in information or documentation.

Since Palermiti \& Polity's 2002 study, the higher education landscape is slowly undergoing transformation. Under pressure from the Bologna process, the French ministry of education has instigated a series of reforms to put France's higher education structure in conformity with european standards. The first of the major reforms is the Licence-MastersDoctorate reform which in 2002 aligned all higher education degrees with european standards so as to fall into the three 'Graduate-Masters-Doctorate' degree levels.

IUP and DESS diplomas have been converted either into a five-year course (three-year undergraduate and two-year masters) or a three-year course where the first year is the graduate year (Licence or Bac+3) and the other two, the master's' degree. A handful of french universities offer a full undergraduate (3 years) and post-graduate (2 years) training in IS. The Institutes of Technology (IUTs) are still in place and delivering the two-year undergraduate technical diploma

\footnotetext{
${ }^{26}$ Diplôme d'Etudes Supérieures Spécialisées

${ }^{27}$ Institut Universitaire Professionalisé.
} 
Ibekwe-SanJuan F., Information science in France. Emergence, Evolution and Perspectives. In. Library and Information Science Trends in Europe, Amanda Spink and Jannica Heinstrom (eds.), Emerald Library and Information science book series $10 / 17$

to students who apply afterwards to a university department to pursue a third year in order to obtain a bachelors' degree and from there go on to a two-year masters' degree. It is difficult to say how many courses or departments offer courses in IS in France because such a department does not have a separate existence and is often embedded with communication or in other departments. A search on the ministry of higher education's website did not yield any meaningful information.

The consequences are rather unfortunate in terms of educational coherence and epistemological emancipation of the field. IS was saddled with bits and pieces of courses gathering students from every other discipline. Each training was constructed as a beginner course in some IS specialty. Consequently, each specialised training produced professionals who had a segmented view of what the field was about, often reduced to their area of technical expertise. This situation also seems not to be unique to France. Indeed, Saracevic (1999) and Bates (1999) complained that IS was a field irrigated by specialists from everywhere else who come into the field easily and perform work based on methods from their own field:

"I see the field of library and information science (L\&IS) as highly centrifugal and greatly in need of high-quality syntheses. Library and information science has always been easy to enter by persons trained in other disciplines, particularly if they bring quantitative skills. The pattern has been many fresh starts by new entrants rather than strong cumulation." (Saracevic 1999, 1052).

\section{Doctoral studies in Information Science}

Here again, a historical approach is necessary to understand the current state of IS research in France and the reason for its dwindling community. Polity (2000) surveyed one of the factors of social institutionalization of a discipline - its production of doctoral thesis. She surveyed thesis production in IS between 1974 - 1994, thus over a 20 year period. We summarise the focal points of her findings hereafter.

Not surprisingly, the first two decades were not very productive with an average of two theses per year defended in IS. Palermiti \& Polity (2002) put this down to institutional resistance from other disciplines which did not wish to see the growth of information and communication science (ICS) and thus resisted the creation of professor positions in universities. The situation has changed since but not necessarily in favor of IS which continues to be in the minority compared to the population of students and professors in the communication science.

It is not surprising that Polity (2000) encountered difficulties in delineating doctoral dissertations that fell under the IS branch. For instance, when searching the national theses database, she found that some dissertations that should haven indexed under IS were wrongly labeled as dealing with "Sciences, techniques and applied mathematics". There was clearly a lack of institutional and social legitimacy as well as ignorance of what IS was and of its very existence in the first two decades. The situation was not helped by the fact that many professors who directed IS theses in the first decade following the creation of the field did not officially change their disciplinary affiliation to the ICS field.

In this period (1974-1994), four main universities were producing doctorate students in IS, namely the EHESS ${ }^{28}$ in Paris, the Pierre Mendès France university of Grenoble 2, Bordeaux

\footnotetext{
${ }^{28}$ Ecole des Hautes Etudes en Sciences Sociales (The School of Higher Studies in Social Sciences).
} 
Ibekwe-SanJuan F., Information science in France. Emergence, Evolution and Perspectives. In. Library and Information Science Trends in Europe, Amanda Spink and Jannica Heinstrom (eds.), Emerald Library and Information science book series 11/17

university and the universities of Lyon (Université Lumière, Jean Moulin and Claude Bernard). The EHESS produced the majority of the theses in those early years. Despite being a social sciences institution, the EHESS hosted a seminar on "Scientific and Technical Information" led by Jean Meyriat $^{29}$ and Madeleine Wolff-Terroine, two of the leading figures in the emerging IS field. Jean Meyriat was a graduate from the Paris School of Political Science. He headed their library for 40 years. Both were also prominent figures in the professional association of documentalists and information professionals (ADBS). Hence, the first theses in IS were of a more technological bent. The majority of the doctoral students were former INTD graduates which trained "engineers" in documentation. Despite this technological orientation, the EHESS has been very instrumental in setting up the first doctoral programs and seminars in IS in France.

The Pierre Mendès France University in Grenoble was the second largest pole by number of $\mathrm{PhD}$ dissertations produced between the late eighties and the early 2000s. This is also a university of the social sciences. The theses were produced under the directorship of Jacques Rouault - a computer scientist specialised in automated documentation and natural language processing (NLP) and under whose guidance the author of the current chapter prepared her thesis. The focus of his research group was on building a large coverage linguistic parser for the French language. The long term vision was that the linguistic models and tools could be the basis for designing specific systems for automatic indexing and information retrieval (IR). Hence, the focus was on formal language models and on information systems rather than on human or on theoretical aspects of IS.

The University of Bordeaux 3 came in the third position in terms of number of theses defended under the directorship of two of the founding fathers of the discipline - Robert Escarpit and Robert Estivals. The latter specialised on "bibliologie" 30 ", a topic on which most of the theses he directed were centered.

The three Lyon universities came in the fourth position. Like the Grenoble group with whom they had a strong collaboration in the early eighties and nineties, the research focus in Lyon was also on NLP, IR and automatic documentation. Most of the theses were done under the supervision of Richard Bouché, a professor that also came from the sciences. The two campuses, Grenoble and Lyon had, for a period of time, co-accredited a doctoral program and helped train a certain number of second generation scholars in IS who are currently professors in different French universities.

In the fifth, sixth and seventh positions respectively were the universities of Aix-Marseille, Paris 8 and Toulouse. The theses in Aix-Marseille were done under the supervision of Henri Dou, an IS professor specialised on bibliometrics. The theses defended in Paris 8 and Toulouse were on more heterogeneous topics as they were done under the supervision of professors who were clearly linked to computer science but working on automating IR applications.

As Palermiti and Polity (2002) observed, a large number of the doctorate students in these first two decades were foreigners from former French colonies in Africa, who later returned to their own countries and hence could not contribute to the epistemological maturity of the field.

${ }^{29}$ Jean Meyriat died on the $26^{\text {th }}$ of December 2010 at the age of 89.

30 The science of books. 
Ibekwe-SanJuan F., Information science in France. Emergence, Evolution and Perspectives. In. Library and Information Science Trends in Europe, Amanda Spink and Jannica Heinstrom (eds.), Emerald Library and Information science book series $12 / 17$

From this survey, it appears that the thesis produced in the first two decades leaned heavily towards technological solutions to some of IS agenda like designing better information systems for indexing and IR. Research on these issues borrowed heavily from NLP (parsers, linguistic models) and from cognitive psychology (understanding information seeking behavior, modeling and manmachine interface design). Little interest was given to social and cultural aspects of humaninformation search behaviour. There was also little research on public or university libraries. More importantly, as Palermiti and Polity (2002) observed, there was no research on knowledge organization (classification theories, models and schemes) whereas this had been a historical heritage and stronghold of French pioneers in documentation (Suzanne Briet, Gérard Coordonnier, Eric and Georgette de Grolier) until the 1960s.

The authors concluded that the strategy for the development of the IS in the first decades rested on individuals rather than on a coherent scientific policy. "About ten professors were responsible for the early development of IS at the doctoral and research level." (Palermiti and Polity, 2002)

However, these first generation professors have retired now. This explains why certain research strains are simply disappearing with the retirement of individual professors who had championed them. It would also explain the difficulties one encounters in trying to identify the contours of the discipline today.

As is the case for graduate and post-graduate courses, students wishing to embark on a doctorate in IS mostly come from other disciplines. Even in the rare case where they have completed a graduate and post-graduate diploma in information-documentation, because of the technological orientation of such courses, they will often lack the necessary theoretical and epistemological background to back up their research. Hence, most doctorate candidates would be "beginners" in IS research with the result that "there could not really be a progression in the content of the different diplomas and no "accumulation of knowledge" (Palermiti \& Polity, 2002). The consequence for the epistemological maturity of a field is predictable: IS in France has not been able to produce the much needed researchers who by accumulation of knowledge, would have helped the discipline mature its concepts, theories and methodologies. The early technological orientation of the curricula in IS, aimed at producing documentation technicians, increased the sentiment among other fields, especially communication, that IS, along with documentation, were technological fields serving other more established and noble disciplines.

However, the tendency these days in IS is to move the towards a more analytical and peopleoriented research.

\section{The quest for institutional and scientific Identity}

Since the early 2000s, the information \& communication sciences (ICS) field as a whole has expanded with more faculty members being recruited and more information-communication departments opening up in universities. However, the picture of the IS landscape described in Palermiti \& Polity (2002) remains largely true. There continues to be a discontinuity in IS courses at different levels, and its scientific community has become even sparser with fewer professors than in the 1980s and 1990s.

The state of the scholarly community 
Ibekwe-SanJuan F., Information science in France. Emergence, Evolution and Perspectives. In. Library and Information Science Trends in Europe, Amanda Spink and Jannica Heinstrom (eds.), Emerald Library and Information science book series 13/17

Palermiti \& Polity (2002) reported that IS scholars surveyed in 1995 could not clearly name sub-domains of the IS field nor identify research teams working in IS. The interviewed scholars had a narrow view of what the field was about, which often boiled down to their own area of specialization. Most felt isolated and thought the field was lacking in internal cohesion. IS scholars had little or no occasion to meet themselves. When asked to name colleagues who worked in the field as themselves, the surveyed IS scholars could hardly come up with more than 2 or 3 names.

Unfortunately, this situation is still true today and if anything has worsened. It is difficult to obtain the number of IS scholars within the ICS field. There is no national database where faculty members can enter their profile and indicate the branch - information or communication in which their activities are primarily based. Indeed, such a question will be deemed "politically incorrect" and probably be interpreted as an attempt to demarcate between IS and IC (communication science), as we are all supposed to be members of 'one big and happy family'. Hence the only figures I have been able to obtain are for the ICS discipline as a whole. As of june 2010, there were 768 full-time faculty members (Enseignants-chercheurs) out of which 170 were full professors (Professeurs des Universités), the remainder (598) were associate professors (Maîtres de conférences). All are civil servants. The difference made between the two categories is that full professors (PR) have obtained a further diploma after their PhD known as the "HDR" (Habilitation à Diriger des Recherches ${ }^{3 l}$ ) and gone through a further qualification stage at the national level, officially authorizing them to direct doctoral research. From some informal discussions I had with colleagues on the topic, it would appear that only about $10 \%$ of the faculty conduct teaching and research which can be seen as falling under the IS field. This gives one an idea of the 'rapport de force' (power tussle) between the information specialists and communication specialists.

Although there is a national association of the ICS discipline named the SFSIC ${ }^{32}$, this association is mainly led by communication scholars. It holds an annual conference focused mostly on communication themes. A proportion of IS scholars and doctorate students gather under the french chapter of the ISKO $^{33}$ which is an international association with national chapters. However, unlike the ASIST in North America, ISKO-France is yet to establish leadership as the representative association of IS scholars in France. Very few IS scholars in France are aware of the ASIST European chapter.

\section{Lack of instruments for academic and cognitive recognition}

Whitley $\left(1974^{34}\right)$, cited in Palermiti \& Polity (2002), contend that there are two ways in which one can look at emerging scientific structures, through cognitive or social institutionalization.

Cognitive institutionalization is the degree of consensus reached on fundamental concepts, on research problems and their formulations, on the capability to distinguish a field from the others and decide if a given research question arises from this field.

\footnotetext{
${ }^{31}$ Authorisation to Direct Research.

${ }^{32}$ Société Française des Sciences de l'Information et de la Communication. Website: http://www.sfsic.org/

${ }^{33}$ International Society for Knowledge Organization. Website: http://www.isko.org/. The French chapter's website: http://www.isko-france.asso.fr/

34 Whitley (R.), 1974, "Cognitive and social institutionalization of scientific specialities and research areas", in Social processes of scientific development, Whitley R. (eds.), London, 69-95.
} 
Ibekwe-SanJuan F., Information science in France. Emergence, Evolution and Perspectives. In. Library and Information Science Trends in Europe, Amanda Spink and Jannica Heinstrom (eds.), Emerald Library and Information science book series $14 / 17$

Social institutionalization on the other hand concerns the creation and maintenance of formal structures seen as belonging to the discipline, which distinguishes its members and gives them a social identity. This concerns the degree of internal organization, the definition of foundations and the degree to which the field is integrated into the social structures for accreditation and for allocating resources i.e.; universities, government institutions, research programs. Fields that have attained a high level of social institutionalization would have a clear body of journals and conferences in which members can publish, a scientific association to which they belong and some institutions with which they interact. The scientific circle can thus clearly be drawn. In fields where this social institutionalization is lacking or is poor, there would be no clear publication avenue (journals and conferences) and no distinction on social basis. The structure of the field would rely more on personal contacts as a means of obtaining information, attaining legitimacy and building internal coherence. Palermiti \& Polity (2002) concluded that there had not been a gainful collaboration between the cognitive institutionalization of IS which began since the early $20^{\text {th }}$ century with Paul Otlet and Briet's works, and their social institutionalization carried out in the early 70 s through the official recognition of the ICS field. Indeed, as they observed, the social institutionalization was done without integrating an important component of the information community, namely librarians and archivists.

This observation is unfortunately still true as write these lines in 2012. IS in France has achieved neither cognitive nor social institutionalization. For a research field to mature, it should have a clear body of journals in which to disseminate its results. This is clearly not the case for IS in France.

Apart from a handful of professional journals and magazines, there is no highly reputed journal that can disseminate research results in IS in France. Although, the journal Documentaliste Sciences de l'information ${ }^{35}$ has published articles written by IS scholars (Hubert Fondin, Y. Le Coadic, Jean Meyriat), it is still mainly a professional journal edited by the ADBS - the association of documentalists and information professionals. Recent reshuffling of its editorial board has led to the inclusion of a few IS professors but the type of articles, their length and the reviewing process have yet to meet international standards for peer-reviewed journals. "Bulletin des Bibliothèques de France" $(B B F)$ is clearly a journal for librarians. The result is that IS scholars often resort to publishing in national communication journals or in national conferences. Publications in english journals are few and far between, one of the reasons being the language barrier.

However, this situation should change as the French government has instigated a research assessment program, conducted by an independent evaluation agency, the AERES - which has begun to evaluate research laboratories and training programs. Individual researchers are also to be evaluated by a national committee for each discipline - the $\mathrm{CNU}^{36}$ - formed by professors from that particular field.

\section{Current research trends in Information Science}

Although Palermiti \& Polity's 2002 study is dated today, it is the only one we know of that gives a

\footnotetext{
${ }^{35}$ Documentaliste - Sciences de l'information.

${ }^{36}$ Commission National des Universités.
} 
Ibekwe-SanJuan F., Information science in France. Emergence, Evolution and Perspectives. In. Library and Information Science Trends in Europe, Amanda Spink and Jannica Heinstrom (eds.), Emerald Library and Information science book series 15/ 17

detailed account of how IS as an academic field was shaped in the first two decades of its existence. The historical part of their study remains relevant. However, we do not share their optimistic conclusion that IS would find ways to gain a better recognition both cognitively and institutionally. This has unfortunately not come to pass. Since the publication of their study in 2002, the space occupied by IS within the ICS discipline has continued to dwindle. There has been an "about-turn" in terms of research orientation. Under pressure from the communication scholars, the second generation of IS professors have been abandoned research of technological line of research laid down by their predecessors, thus leaving information systems design solely to computer science. It is has become de "bon ton" for IS scholars to embrace only human-oriented issues, borrowing methodologies from "acceptable" social sciences and humanities disciplines (sociology, ethnology, anthropology and history), rather than from linguistics and computer science. However, this change of orientation (or this return) to the humanities has not brought about an increase in the visibility of research in IS nor a clear focus on theoretical and epistemological foundations of the field. We are yet to see a revival of interest on knowledge organization theories and paradigms. Indeed, it is difficult nowadays to say precisely what IS scholars in France are working on.

Consequently, and owing to other mitigating factors (the dwindling number of faculty members, the lack of institutional and peer recognition), the number of students wishing to pursue doctorate studies in IS has also steadily declined. Indeed potential PhD students, not having a clear view of what IS is really about nor what IS scholars are working on, would prefer to enroll with computer science professors if they are clearly interested in design of information systems or with humanmachine interface design. They would enroll with communication professors if their focus is on social or human-related aspects of IS. What then is the object or the 'specificity' of IS in France? What place does it have or can it claim have in the French information and communication science (ICS) field? It is to be hoped that the next decades will begin to address these issues.

\section{Perspectives}

The inconsistent public policies implemented by the different French governments between the early 1960s and 1990s affected the development of what remains of Information Science in France.

The way universities and higher education systems are managed affects the evolution of disciplines. France has up until very recently had a tradition of centralised government. The ministry of higher education has been the main policymaker, giving accreditation for curricula in every field and dispensing the corresponding funding. The current right-wing government has implemented some reforms since 2007 aimed at moving universities towards more autonomy and self-governance. However, it appears to be a case of autonomy on a leash. The ministry of higher education still retains the rights to accredit courses, to deliver university diplomas and accredit research units. In the current higher education landscape, information science will be hard put to maintain its current level of staff recruitment and courses.

Research in IS in France has also been shaped by the first generation of professors in the early 1980s and 1990s who came mostly from the sciences and relied heavily on advances in Artificial Intelligence (AI) and Natural Language Processing (NLP). That period (1975-2000) 
Ibekwe-SanJuan F., Information science in France. Emergence, Evolution and Perspectives. In. Library and Information Science Trends in Europe, Amanda Spink and Jannica Heinstrom (eds.), Emerald Library and Information science book series $16 / 17$

marked the predominance of "the linguistic and AI turn".

The early 1980s and 1990s can be seen as the boom in IS, when the field was nascent and drew a lot of people from other disciplines. Most of the research themes developed in that period (system's design, automatic indexing, OPACs design, user studies in IR) are being phased out of the discipline and left solely to computer scientists and to cognitive psychologists.

The context of cohabitation with communication science where the latter has at least four times more researchers and students makes it infinitely more difficult for IS to flourish.

Led by a second generation group of scholars inspired by hermeneutics, socioconstructivism and systemic theory, IS research in France is currently leaning heavily towards more human-oriented issues. Fields like linguistics and computer science have become disciplina non grata and technologically-oriented research is now viewed with a lot of suspicion. If the humanistic trend brings about a refocusing of IS on a clear research agenda and increases its visibility on the national and international arena, that will be all to the good. However we are yet to see signs of any coherent research agenda or a body of theories and paradigms governing the current orientation. What IS has witnessed is a swing from one end of the spectrum (technology and computer science) to the other (purely humanistic one) with little or no space left for research combining the two, which in our view, is the "way forward" for information science.

Information science should not confine itself only to analytical discourse and theoretical reflections. We are in agreement with Marcia Bates (1999) when she stated that the methodological substrate of the discipline is of a socio-technical nature. Information science needs to address three types of research questions: conceptual models and theories, user studies and systems design in order to meet its research questions. Re-engaging information science in systems design matters will enable its community to shed a more humanistic light on design considerations and ensure that systems design meet user needs and requirements. Information seeking behaviour has always been a traditional research topic in IS. Yet these and topics related to knowledge organization have been largely neglected by the majority of IS scholars in France and left to cognitive scientists. It is not certain that the current orientation which is without a clear agenda will help to better delineate the IS from other humanities and social science fields such as sociology, history, anthropology, ethnology from which it borrows methodologies and theories. However this problem is not peculiar to French IS alone. Marcia Bates (1999: 1049) also observed what she called "a great methodological shift sweeping the social sciences, the shift to the qualitative, multiple-perspective, post-Modernist approaches."

At the present, the future of information science in France is uncertain and there is a fair amount of anxiety among its community. Information science scholars in France will gain by becoming more active in international associations. A few researchers and professionals are involved in professional organizations such as ISO and IFLA. A handful more have always been involved in scientific societies such as ISKO (International Society for Knowledge Organization). More effort is needed to organize the community such that it becomes visible on the international arena. Involvement with other scientific bodies worldwide may help in identifying colleagues, institutions, and trends from other countries, in understanding the dynamics of the discipline in those countries and in strengthening the network in Europe and elsewhere. Also, joint proposals for funded project will be another avenue for information science researchers in France to strengthen their research portfolio and network.

\section{References}


Ibekwe-SanJuan F., Information science in France. Emergence, Evolution and Perspectives. In. Library and Information Science

Trends in Europe, Amanda Spink and Jannica Heinstrom (eds.), Emerald Library and Information science book series 17/ 17

Bates M.J. (1999), The invisible substrate of information science, Journal of the American Society for Information Science, 50 (12), 1043-1050.

Buckland, M., (1996), Documentation, information science, and library science in the USA, Information Processing and Management, 32(1), 63-76.

Cacaly S., Le Coadic Y., (2007), Fifty years of scientific and technical information policy in France (1955-2005), Journal of Information Science, 33 (3), 2007, 377-384.

Fayet-Scribe, S., (2000), Histoire de la documentation en France : culture, science et technologie de l'information (1895-1937), Paris: CNRS editions.

Fayet-Scribe, S., (1997), The cross-fertilization of the U.S. public library model and the French documentation model (IIB, French correspondent of FID) through the French professional associations between world war I and world war II, Journal of the American Society for Information Science, 48(9): 782-793.

Ibekwe-SanJuan F. (2012), The French conception of Information Science: une exception française?, Journal of the American Society for Information Science. Forthcoming.

Palermiti, R., Polity Y., (2002), Dynamiques de l'institutionnalisation sociale et cognitive des sciences de l'information en France, In Boure R. (ed.), Les origines des sciences de l'information et de la communication : regards croisés. Presses Universitaires de Septentrion, Villeneuve d'Ascq, 2002, 95-123.

Polity, Y., (2000), La communauté scientifique des Sciences de l'information, Communication au groupe de travail Théories et pratiques scientifiques (TPS) de la SFSIC, 3 mars 2000.

Salaün, J.M., (1991), La fin de l'IST ? Histoire des politiques publiques en information scientifique et technique. Rapport de recherche CERSI-ENSSIB, 40p. Online at http://www.enssib.fr/bibliotheque/documents/travaux/salaun.pdf. Visited on 12/12/2010.

Salaün, J.M., (1993), Les sciences de l'information en question. Online at http://www.archivesic.ccsd.cnrs.fr/docs/00/06/20/53/RTF/sic_00000048.rtf

Tétu J-F., (2002), Sur les origines littéraires des sciences de l'information et de la communication, In Boure R. (ed.), Les origines des sciences de l'information et de la communication : regards croisés. Presses Universitaires de Septentrion, Villeneuve d'Ascq, 2002, 71-93.

Williams, R.V., (1997), Documentation and special libraries movements in the United Sates, 19101960, Journal of the American Society for Information Science, 48(9): 775-781.

\section{Short Bio}

After completing a PhD in Information Science at Stendhal University, Grenoble (France), Fidelia Ibekwe-SanJuan became an Associate Professor in Information science, a position she has held in three different french universities. She is currently a faculty member of Information \& Communication Sciences at Jean Moulin University in Lyon (France). She has authored several peer-reviewed articles in areas of research such as domain knowledge mapping, text mining, information retrieval. She has been working lately on the theoretical foundations of Library and Information Science with a view to comparing the french and anglosaxon ones. She is also a member of ISKO and the European chapter of the ASIST where she has held borad positions. 